Miceli Junior, G., Pellanda, P. C. and Reis, M. C. (2020). "Management procedure for sensitive projects in the context of a BIM adoption in a public organization" In: Proc. 37th CIB W78 Information Technology for Construction Conference (CIB W78), São Paulo, Brazil, pp. 232-247. DOI: http://dx.doi.org/10.46421/2706-6568.37.2020.paper017

\title{
MANAGEMENT PROCEDURE FOR SENSITIVE PROJECTS IN THE CONTEXT OF A BIM ADOPTION IN A PUBLIC ORGANIZATION
}

\author{
Giuseppe Miceli Junior ${ }^{1}$, Paulo C. Pellanda ${ }^{2}$, and Marcelo C. Reis ${ }^{3}$
}

\begin{abstract}
The increasing adoption of Building Information Modeling (BIM) in the management of Architecture, Engineering and Construction design processes has intensified digital information among stakeholders. If strategic and sensitive projects are developed for the public environment, BIM deployment must have additional characteristics. This paper aims to propose processes for project planning management, applying it to a public organization that has its own project teams for the development of military projects. It is based on the adaptation of ISO 19650-1 and ISO 19650-2, which standardizes the creation, management and use of information contained in models, and the design of ISO 19650-5, which standardizes security-minded procedures for models and digital built environments. Activities within all procedures were summarized in three main management groups that have shown to be interconnected: management of the model with information security procedures, product management and the public governance management. The processes were then evaluated in a sensitive design, in respect to their applicability in a design office. As a result, while product and governance management groups have increased its efficiency with BIM implantation, model management still takes time to present optimum efficiency, thanks to little knowledge of BIM professionals in sensitive aspects of the project.
\end{abstract}

Keywords: Collaborative Design, Building Information Modelling, Sensitive projects, Public organizations.

\section{INTRODUCTION}

Project is generally understood as the temporary effort with the intention of creating an exclusive product, elaborated progressively in stages, being submitted to planning, execution and control (PMI,2015). The information flow during project development has become more intense, making necessary to develop Information and Communication techniques in order to manage the increasing flow and, at the end of the project, to meet their demands.

Building Information Modeling (BIM) is defined as a set of associated technologies, processes and policies to produce, communicate and analyse constructive models, enabling stakeholders to collaboratively design, build and operate a facility (Succar,2009; Eastman et al. 2008). Around the world, BIM has been successfully applied worldwide by companies and organizations; being a common practice in design process in countries

D.Sc., Military Institute of Engineering, Rio de Janeiro, Brazil, giuseppe.pged@ime.eb.br

Dr. ENSAE, Military Institute of Engineering, Rio de Janeiro, Brazil, pcpellanda@ieee.org

D.Sc., Military Institute of Engineering, Rio de Janeiro, Brazil, marceloreis@ime.eb.br 
like Sweden, Australia, China, the United States, the Netherlands, Finland, Norway and the United Kingdom (Gu et al. 2011; Cheng and Lu, 2015).

However, many organizations still tend to believe that having a modeling software to produce design models is enough to practice BIM, restricting its benefits to the purchase of a 3D modeling tool. Other organizations tend to buy several software suites that have got little interoperability among them. One can tell that any BIM adoption centered only in technology field has little chance of success.

This work aims to develop a management procedure in the context of a BIM adoption in a Brazilian public organization, applying it in one of its design offices which develops its own sensitive projects. In this way, BIM adoption must contemplate some requirements in respect to information security, submission to public compliance and specific project conditions.

\section{LITERATURE REVIEW}

\subsection{Management actions in BIM adoption}

BIM adoption in public environments is generally based in several sets of factors that may influence its outcomes, but in a different shape from those adoptions developed in private companies.

Some researchers (e.g. Manzione,2013; Pereira,2017; Souza,2016; Franca, 2016) developed conceptual structures where management actions in the building information model (BIModel) always have correspondence with product development phases.

In public organizations, however, BIM adoption must consider public governance actions, in order to support all actions related to model and product development. A public-partnership association may be mandatory for the success of the BIM implementation and design maturity (Porwal and Hewage, 2013)

Based in a previous work, Miceli Junior et al. (2019) classified all these factors into three groups of actions, describing the interaction among them in a tri-axial BIM adoption framework, illustrated in Figure 1 and better described in the next sections.

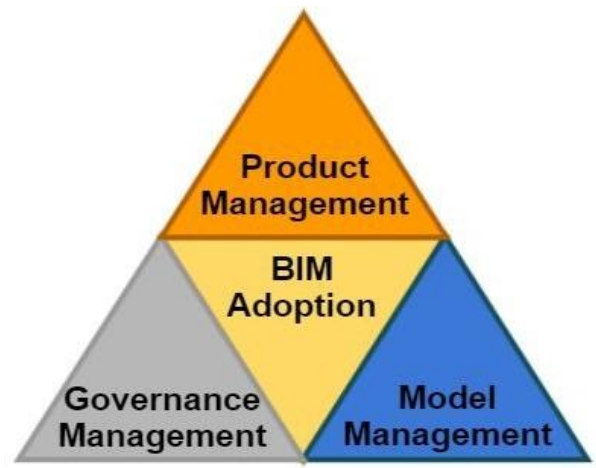

Fig. 1. Management groups in BIM adoption (Miceli Junior et al. 2019).

\subsubsection{Model management.}

Related to the use of BIModels in process management and all related specifications, including BIM adoption and its implementation effort in organizations. International standard ISO 19650 describes all concepts and principles regarding model management, as well as the description of all delivery phase of the assets. Until now, it is divided in two parts, with other two parts in final revision. 
ISO 19650-1 (2018a) defines the concepts and principles regarding the information delivery cycle in all stakeholders' perspectives and design collaboration. On the other hand, ISO 19650-2 (2018b) defines information delivery process and divides it in eight phases that will be briefly explained:

- Assessment and need: With the definition of all rules, responsibilities and activities for information management with all necessary specifications and obligations.

- Invitation to tender: All information and requirements regarding to the information flow and its management must be defined and compiled in tender documents, so that the public or private market become aware of the bid process.

- Tender response: The bidding company should develop its own tender documents, based in the selection of the project team, assessing their capacity and ability (ISO, 2018b; Holzer, 2016).

- Appointment: At this stage, the contractor must confirm the pre-contractual BEP established by the winning bidder, establishing a post-contractual BEP including all BIM workflow guidelines (ISO, 2018b; Holzer, 2016).

- Mobilization: All processes, policies and technologies pre-established in the delivered BEP are tested by the contractor. (ISO, 2018b).

- Collaborative production of information: It is based on collaborative production, based on the modeling process itself, with high BIM tool interoperability and broad collaboration among professionals. (ISO, 2018b).

- Information model delivery: Consolidation of all project deliverables: documents, BIModels and all data produced. It is the phase where the contractor makes the final verification of the project model, concluding by its acceptance or not.

- Project close-out: Archive of the CDE and consolidation of all lessons learned for futures projects, including them in future adaptations of the PEB.

\subsubsection{Product management.}

It is related to product adequacy to client technical specifications and compliance with deadlines and costs, as well as how constructions are designed by the design team.

Although there are different definitions and standards for which project phases exist, they generally follow a sequence. For example, Brazilian standard NBR 16636 divide project effort in a design preparation phase, including feasibility studies, preliminary and specific data collection and location definition; and a technical design development phase, including draft development and construction design itself (ABNT,2017).

The modelling process of all disciplines and the related federated BIModel are always developed by the project team, along with product management and great participation and aid of the team of BIM champions.

\subsubsection{Public governance management.}

Related to the submission of all project effort to external governance and auditing rules in order to ensure and its accountability to citizens. In general, a public organization must always be accountable for its actions and expenditures, so BIM adoption processes must take this fact into account.

Unlike other two groups, governance management activities are not sequential, but all of them permeate the entire project process. Activities where governance tasks are 
paramount to ensure a good project development and BIM deployment can be summarized as follows:

- Demand of the organization direction for starting a new project.

- Requirements definition for project development, cost and schedule management.

- Provision of conditions for project team to develop the project (budget prediction and authorization for bidding).

- Definition of bidding processes for services and admission processes to select professionals necessary to enable design and product development.

- Bidding process itself and contract award.

A deep integration between product management (e.g. schematic design, full design) and model management activities (e.g. model evaluation, design model) is suggested through project process (Pereira,2017; Souza,2016). Unfortunately, in most countries, Brazil included, there is little legal support for non-DBB bidding and procurement process, so most BIM public projects, if not all of them, follow DBB pattern, failing to guarantee the integration.

\subsection{Information security in sensitive projects}

The main reference standard that deals with security information is British standard PAS 1192-5 (2015), in update process to the future ISO 19650-5 standard. It presents requirements for the management of projects developed in digital technologies, for information security in building information models, digitally built environments and intelligent asset management (ISO, 2019; BSI,2015).

Sensitive assets are those facilities that comply with diplomatic, security, national defense or law enforcement, or any facilities that may be used to compromise the integrity of the asset built as a whole or its ability to function (ISO, 2019). Also, according to this PAS, the specific attributes that considered as sensitive within a project minimally include location and data on:

- Control and surveillance systems.

- Permanent machinery.

- Control, access and security rooms.

- Cabling and installations related to previous systems.

- Structural design details.

- Technical product specifications and safety characteristics.

It is also established a sequence of activities with the intention of carrying out the project, through its execution and supervision the whole construction operation.

Activities start with a security triage process in order to determine whether a security-minded approach is required in relation to the project to assess the level of information safeguard that should be adopted, both in relation to asset construction and its neighboring assets. A security manager also should be appointed by the entrepreneur, who will be responsible for all advisory and security procedures to be developed thereafter.

Security-minded approach must be developed alongside a holistic view of the security threats and vulnerabilities that may arise in project process, everything involving all BIM fields: technologies, politics and processes (Succar,2009). From this point of view, 
security-minded approach shall be developed alongside the sequence described in ISO 19650-2.

After security triage process, a security strategy must be settled, including assessment of all specific security risks arising from the new level of technology involved in BIM adoption, the potential risk mitigation measures, a summary of the tolerated security risks and the review and update policies for the security strategy. It should include all personnel, physical, technological aspects, as well as the information security policies and process which will influence the BIM execution plan development (BSI,2015).

From the security strategy, a security management plan shall be developed by the organization, which will be also responsible for its maintenance and implementation. The plan shall contain all requirement related to the provision of information and to installation of any security assets and systems. A security breach/incident management plan shall be created and maintained (BSI,2015).

\section{RESEARCH STRATEGY}

Design Science Research was used in this research. It is a methodology that seeks to close the gap between the theory and the practice, working collaboratively with organizations to test new ideas in real contexts (Dresch et al. 2015).

The artifact developed in this research consists with the creation of a set of processes based in an adaptation from ISO 19650 and PAS 1192-5. All processes tend to be applied to a public organization, which has design offices spread throughout Brazil; each of these organization offices have its own design team and are also responsible for the lifecycle management of all facilities inside their occupation area.

For the development of the artifact, one sought to survey the current state of the BIM implementation in the organization, in order to know the starting point from which all BIM adoption efforts would begin.

Prior to project initiation, organization's processes were then studied, through faceto-face interviews and some reunions among the researcher and the organization professionals during the second semester of 2018. All reunions aimed to collect all data regarding all management processes related to design development.

The project which will be described in Section 5 has specific requirements, both for the BIM implementation and for the design development. Because of its sensitive characteristics, security measures related to design development of the BIModel were also studied. All processes were then divided intro the three management action groups defined in Section 2.1, also considering all necessary security measures for its development.

\section{ARTIFACT DEVELOPMENT}

Based in prior works about BIM implantation in public organizations (Miceli Junior et al. 2019), the artifact was developed by integrating the three management groups with security-minded measures, as shown in Figure 2. One can observe the governance management activities were initiated was the decision of the authority responsible for the construction of the work. That phase is followed by the definition of the construction plan for the current year and its consequent communication to all design offices.

The next phase within the governance process group, represented in brown boxes, is project planning. It directs all of project's upcoming planning efforts and It must provide all conditions for both BIM deployment and project development. 
Based in initial project planning, all efforts to acquire the necessary resources (hardware, software, new network solutions, common data environment), contracting auxiliary services (topographic surveys, geotechnical surveys) and hiring of personnel (professional and technical personnel) are started and conducted based in well-defined bidding documents that have undergone prior legal analysis.

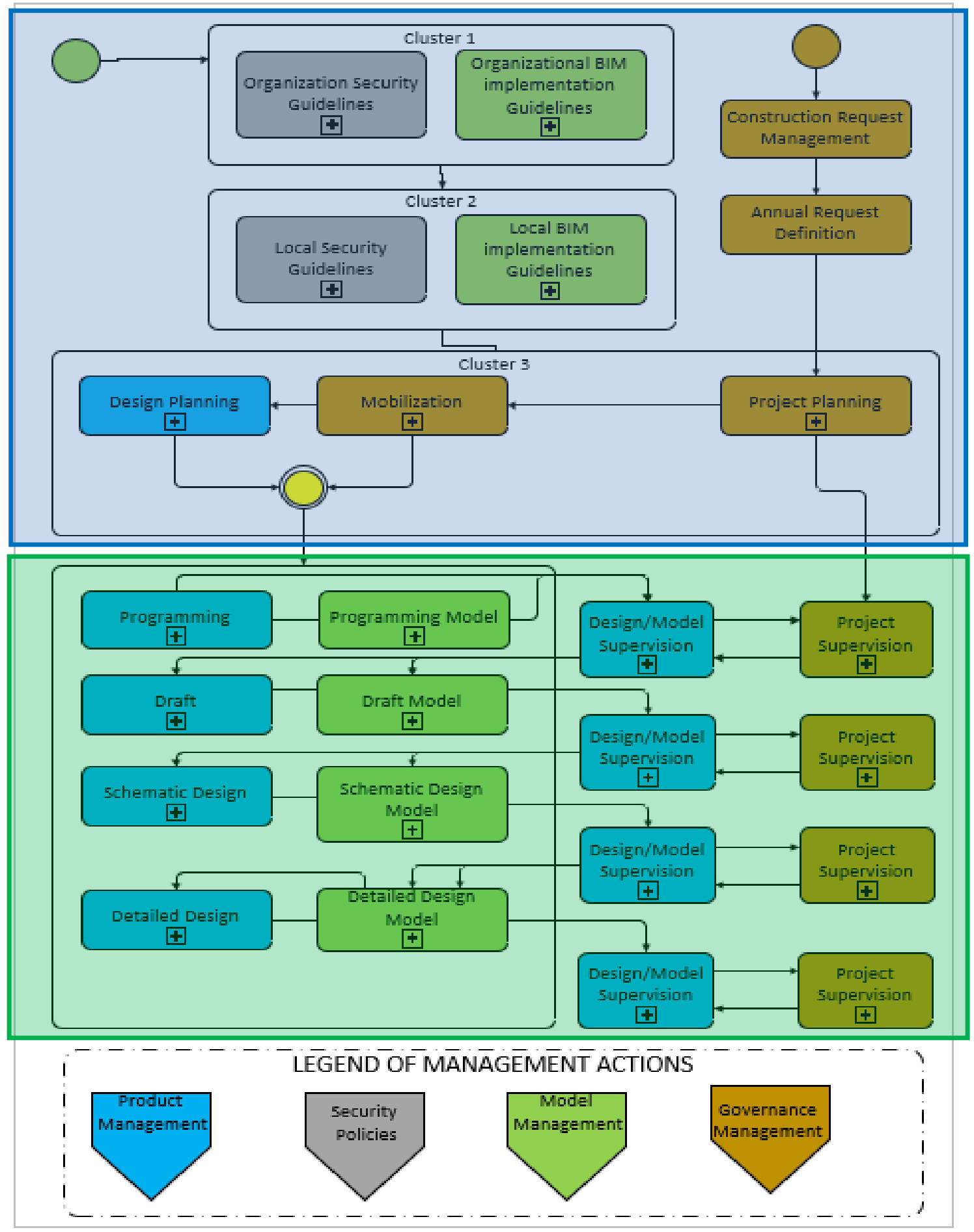

Fig. 2. Proposed framework for this research. Blue rectangle represents design planning phase while green rectangle represents design development with collaborative production of information. 
In this work, model management actions, represented in green boxes in Figure 2, are split into two groups, where are defined all necessary organizational guidelines and local guidelines. In the other hand, product management actions, represented in blue boxes, guard a deep relationship with model management ones, partially because BIModel is always developed simultaneously to design: the more developed it is, higher are the level of development of construction components.

While organizational guidelines include the appointment of the information team and the definition of the conditions BIM would be adopted in the public organization, local guidelines generally include the appointment a BIM manager or an office information team and outlines how BIM will be adopted in the office. Example of local guidelines documents are the BIM implementation plan, the BEP, and the project execution plans.

All security measures related to BIModel creation, in this research, follow a defined sequence inspired in PAS 1192-5, being represented in grey boxes in Figures 2 and 3. Regarding a sensitive design project, they must be defined before project beginning and must guard a broad relationship with organizational and model development activities.

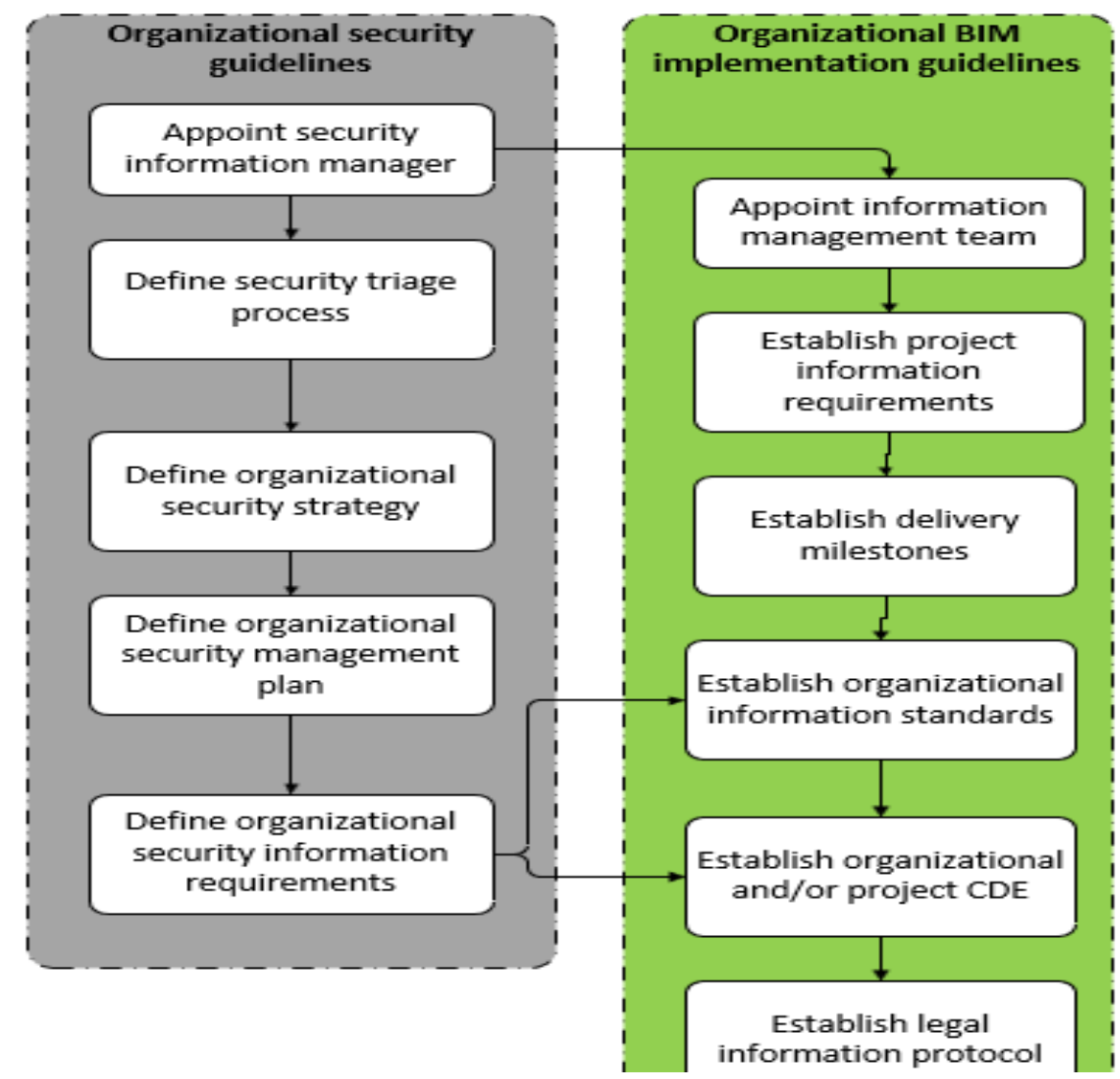

Fig. 3. Relationship between organizational security and organization BIM implementation guidelines

A master process model modelled in BPMN, with all the sequence between all the processes from all three management groups, was developed with all 85 constitutive processes that were created for this framework. Due to its extension, it will not be represented in this work, but Figure 3 shows an extract of the process, which details the relationship and the sequence of model management group activities and their related security guidelines. 
In addition, a task chart was still created in order to detail the master process model into lesser activities. Three examples will be given to illustrate how task chart are organized: Figure 4 shows the sequence related to the organizational security measures process, while Figure 5 shows the sequence related to the organizational BIM implementation.

\begin{tabular}{|c|c|}
\hline MAIN PROCESSES & $\begin{array}{c}\text { TASK CHART } \\
\text { Organizational security measures }\end{array}$ \\
\hline $\begin{array}{l}\text { Appoint security } \\
\text { information manager }\end{array}$ & $\begin{array}{l}\text { Choose a security manager who will responsible for monitoring the development of digital security aspects in } \\
\text { the development of the project. }\end{array}$ \\
\hline $\begin{array}{l}\text { Define security triage } \\
\text { process }\end{array}$ & $\begin{array}{l}\text { Categorize the types of projects, according to their security needs. } \\
\text { Choose quick questions that can characterize and quantify the risks of the safety information of BIModels. } \\
\text { Model information security screening process. }\end{array}$ \\
\hline $\begin{array}{l}\text { Define organizational } \\
\text { security strategy }\end{array}$ & $\begin{array}{l}\text { Identify and record high-level security risks related to the safety of people. } \\
\text { Identify and record high-level security risks related to the safety of the processes. } \\
\text { Identify and record high-level security risks related to physical security of the built asset. } \\
\text { Identify and record high-level security risks related to its technical and cibernetics aspects. } \\
\text { Assess each security risk raised, classifying them as acceptable or not. } \\
\text { Identify possible mitigation measures and accepting risks that are residual. } \\
\text { Define the mechanisms for reviewing and updating the security strategy. }\end{array}$ \\
\hline $\begin{array}{l}\text { Define organizational } \\
\text { security management } \\
\text { plan }\end{array}$ & $\begin{array}{l}\text { Develop all built asset aspects that will be covered by the security plan regarding personnel. } \\
\text { Develop all built asset aspects that will be covered by the security plan regarding processes. } \\
\text { Develop all built asset aspects that will be covered by the security plan regarding its physical security. } \\
\text { Develop all built asset aspects that will be covered by the security plan regarding its technical and cibernetics } \\
\text { aspects. } \\
\text { Develop all built asset aspects that will be covered by the security plan regarding its logistic issues. } \\
\text { Define requirements for the storage and protection of information as long as necessary. } \\
\text { Define the mechanisms for reviewing and updating the plan. }\end{array}$ \\
\hline $\begin{array}{l}\text { Define organizational } \\
\text { security information } \\
\text { requirements }\end{array}$ & $\begin{array}{l}\text { Detail asset information requirements with respect to the arrangements for secure capture, handling, } \\
\text { dissemination, storage, access and use of all data and information relating to sensitive assets and systems. } \\
\text { Detail the arrangements for safekeeping and project data that need to be stored, as well as the access registry. } \\
\text { Detail the quantity and quality of the project information to be stored in CDE } \\
\text { Confirm arrangements for the production of separate BIModels for specific purposes or volumes, aimed at } \\
\text { security-oriented systems. }\end{array}$ \\
\hline
\end{tabular}

Fig. 4. Process modelling and task chart related to organizational security measures 


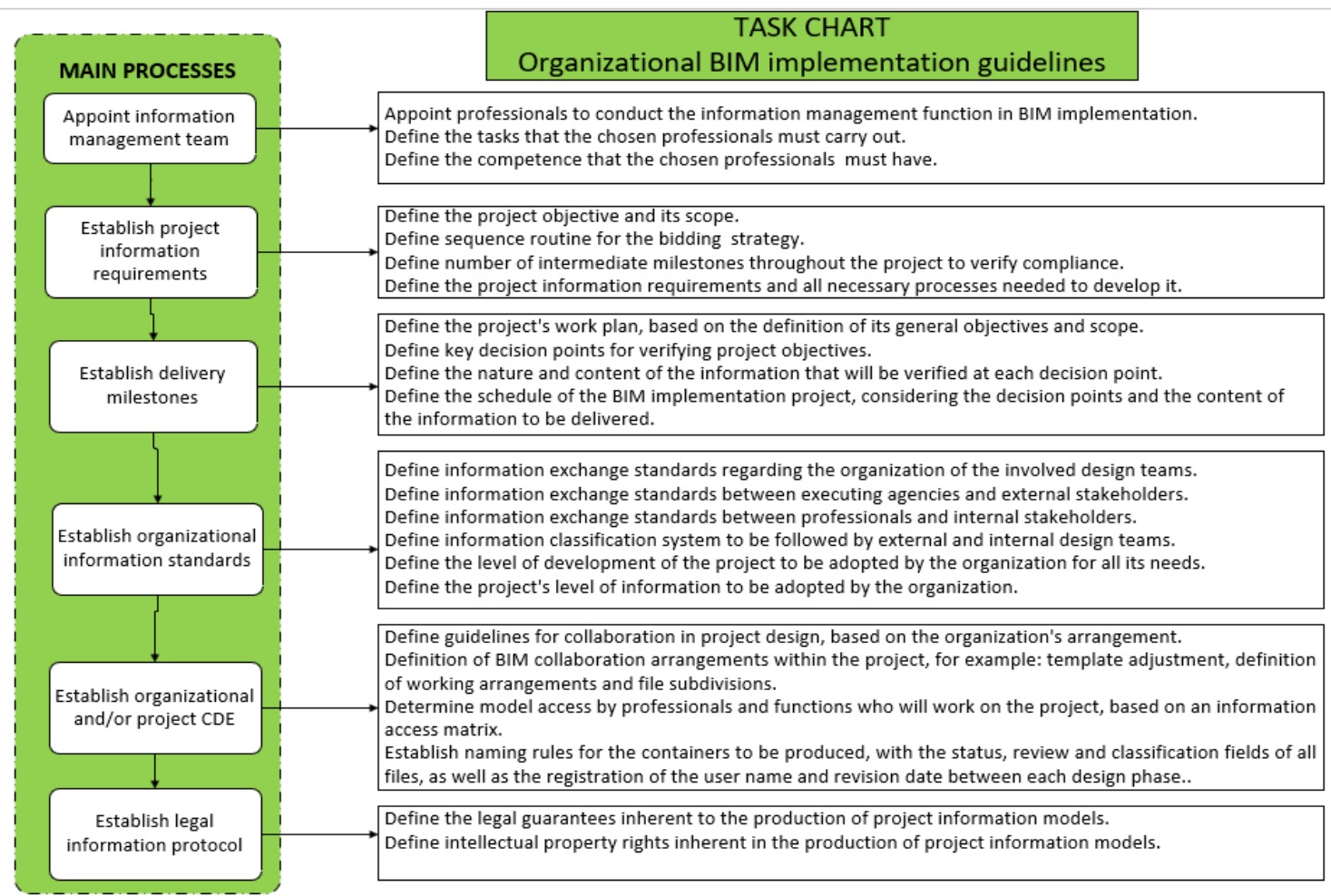

Fig. 5. Process modelling and task chart related to organizational BIM implementation

\section{ARTIFACT APPLICATION}

To evaluate all procedures created, in respect to its applicability to a sensitive environment, an artifact application was developed in an organization which is currently considered one of the references in BIM usage in Brazilian public service.

The experiment took over in a design office specialized in design development, during the second semester of 2018, period when face-to-face interviews and case studies were conducted. All projects are generally destined to the military use, like headquarters and barracks, that always follow a standardization through standard projects or reference projects.

However, this project, which was supervised in this research, has got specific requirements. It will be built in an area of about 20,000 square meters, with a constructed area on a plot of about 28,000 square meters, formed by a building with five floors, being them underground, ground and three floors.

It will have specific security-related rooms and special security installations. Due to project order of magnitude and its sensitive design, a BIM implementation with some special characteristics became mandatory.

\subsection{Brief project description}

Since project initiation, it develops basically as the synergy of two separate projects: the design development itself and the BIM implementation in the project office. BIM implementation in project office aimed to optimize collaborative work within the project process, obtaining all necessary means - personnel, hardware, software and networking solutions - to guarantee its success. 
A BIM outsourced consultancy was also contracted, whose mission was the technology transfer as a progressive process of BIM implementation, involving development of a $\mathrm{BEP}$, component library development and all necessary software training and support for adequate design development.

After consultancy contract award, diagnostic meetings between the consultant and office representatives were then held. The deployment sequence developed by the consultancy was based, with due adaptations to the office environment, in the steps defined in the BIM Project Execution Planning Guide, from Pennsylvania State University (PSU, 2011). First case uses to be developed were the design authoring, 3D coordination, cost estimation and phase planning, so that the technical requirements, budget development and schedule planning were directly included from beginning of the design.

A Common Data Environment (CDE) was created within existing organization network, where all professionals had to develop their model designs. The use of any cloud based CDE, as well as any cloud communication platforms, has been banned.

Interoperability between software were then based in proprietary file formats, when software was part of the same suite, and IFC (Industry Foundation Classes). However, in both cases, when any software was not IFC-compatible, even DXF file format was used. All interoperability guidelines were included in the BEP, and all interaction between them as represented in Figure 6, which shows BIM tool ecology and its X axis corresponding to design evolution.

Geometric coordinates are shared from the design beginning, either through work sets or through model links to a federated model. Design model is formed by 26 different models, and generally their creation is based in the design disciplines, the number of the engineers and architects involved, and convenience for information security.

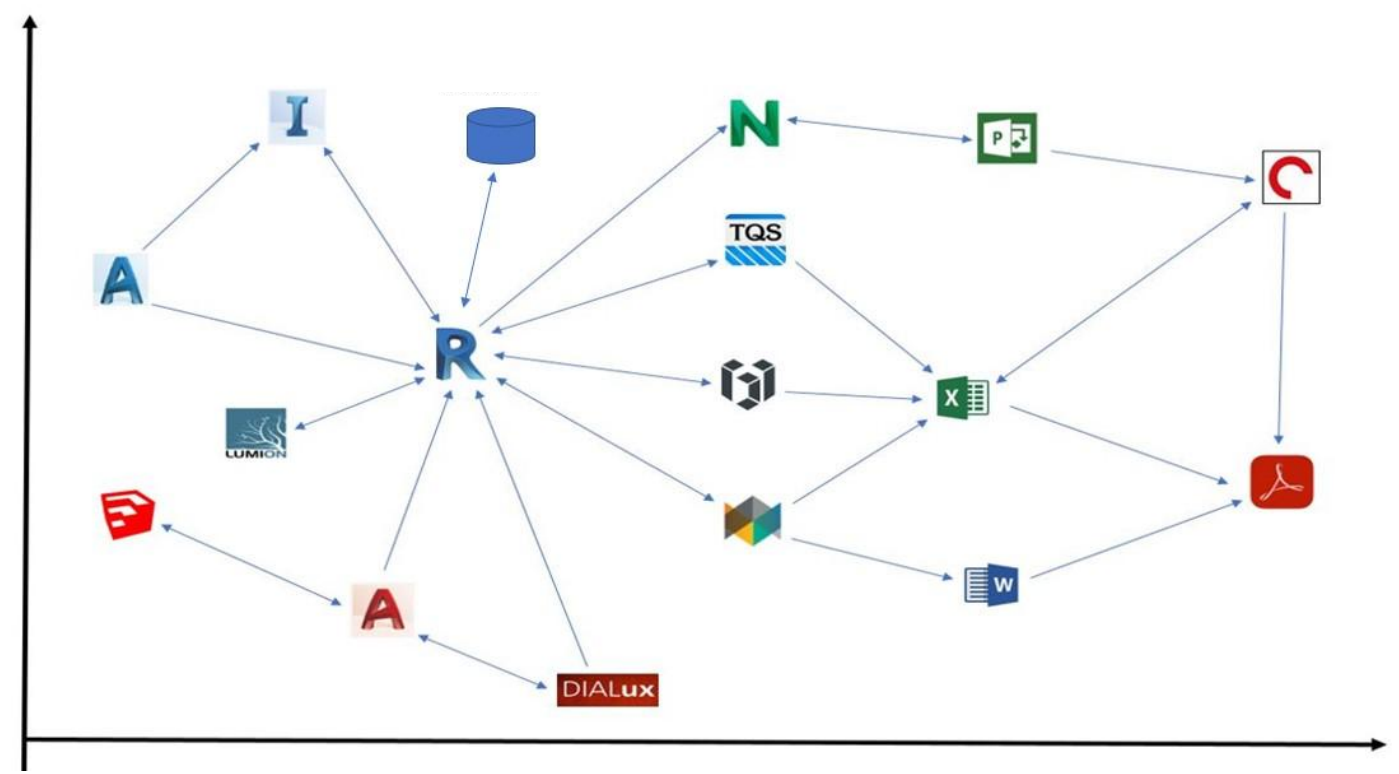

Fig. 6. BIM tool ecology for the office, emphasizing all interactions among software and information

Table 1. BIM and not-BIM software in the BIM tool ecology displayed in Fig 6.

\begin{tabular}{|l|l|l|}
\hline USE & SOFTWARE & LOGO \\
\hline
\end{tabular}




\begin{tabular}{|c|c|c|}
\hline Drafting & Trimble SketchUp & \\
\hline 2D Drawings & Autodesk AutoCAD 2018 & \\
\hline 3D Models & Autodesk Revit 2018 & \\
\hline $\begin{array}{l}\text { Clash Detection and } 4 \mathrm{D} \\
\text { Simulation }\end{array}$ & Autodesk Navisworks 2018 & \\
\hline Infrastructure Design & Autodesk Civil 3D 2018 & \\
\hline Structural Design & TQS 20 & TQS \\
\hline Structural Design & AltoQI Eberick 2018 & \\
\hline MEP Design & AltoQI QI Builder 2018 & \\
\hline Lighting Simulation & DIALux & DIALux \\
\hline Text Editor & Microsoft Word 2017 & $w$ \\
\hline Spreadsheet Creation & Microsoft Excel 2017 & \\
\hline Rendering & Lumion & \\
\hline PDF Documents & Adobe Reader & \\
\hline Project Planning & Microsoft Project 2017 & 而 \\
\hline Project Budgeting & Compor90 & \\
\hline
\end{tabular}

All design development was developed over several meeting cycles, expanding from design programming to schematic and detailed design using BIM software. Thus, with specific software at their disposal, the collaboration and interoperability procedures made clash detection easier and more efficient.

$4 \mathrm{D}$ planning efforts were also carried out, following a defined process based in the extraction of the quantity take-offs from all discipline models. 5D planning was also based in these QTO, although there was no direct interface of BIM authoring tools and the budget development software adopted. Although budget process was constantly error-prone, an experienced planner revised project budget and schedule all the time.

Nowadays, detailed design is near completion. The stakeholders seek from federal agencies the money needed to bid and contract the construction.

\subsection{Artifact evaluation}

In this research, the framework will be evaluated in the planning phase of the project, represented with a blue rectangle in Figure 4. Although a total of 45 process were defined in this project phase during this research, only the more representative ones are evaluated in this work.

All process models and task charts, which were created, have had their applicability evaluated. According to its applicability, that is, the way how developed models and task charts could be applied in a sensitive project environment, each process was classified in 4 categories: 
- not applicable: no task could not be applicable in the organization design process.

- not relevant: where few tasks could be applicable.

- very relevant: where most tasks could be applicable.

- totally applied: where all tasks could be applicable.

\subsubsection{Product Management.}

These activities were already integrated to day-to-day activities, actually because of the high definition and consolidation of rules for project planning and design development, as showed in Table 2. Since design initiation, they have involved not only design development activities, but all efforts related to design decision-making meetings and availability of all data and information to all stakeholders. All design phases related to the collaborative production of information are still in development, so they are not represented in this research.

Table 2. Evaluation of applicability and relevance of the process created.

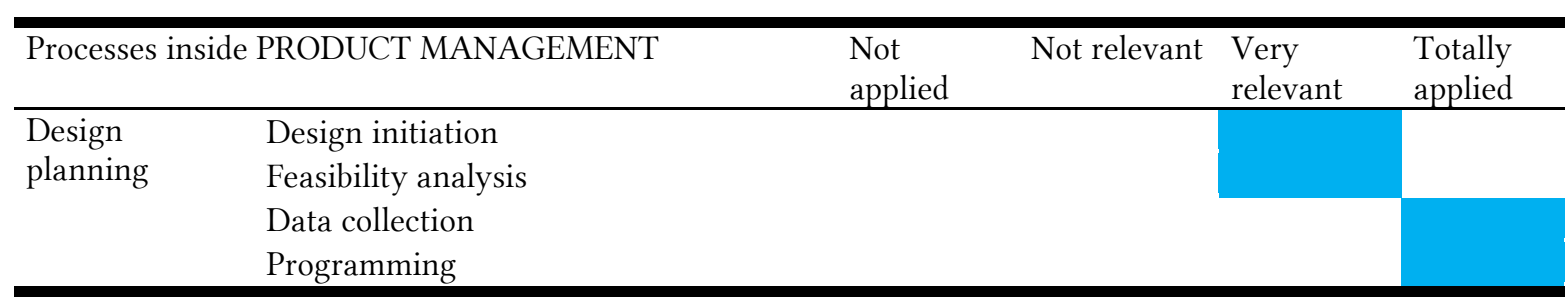

\subsubsection{Governance Management.}

In general, governance management activities are already well-defined and integrated to design office, as showed in Table 1. Because of the BIM implementation and all effort required for its adequate development, some difficulties were encountered.

The first reason is the innovative characteristic of a public project and its compatibility to rigid governance rules and related bidding acts. The second reason, principally in the consultancy bidding process, is the lack of comprehension of some specific concepts of BIM by bidding and legal managers.

Table 3. Evaluation of applicability and relevance of the process created.

\begin{tabular}{|c|c|c|c|c|c|}
\hline \multicolumn{2}{|c|}{ Processes inside GOVERNANCE MANAGEMENT } & $\begin{array}{l}\text { Not } \\
\text { applied }\end{array}$ & $\begin{array}{l}\text { Not } \\
\text { relevant }\end{array}$ & $\begin{array}{l}\text { Very } \\
\text { relevant }\end{array}$ & $\begin{array}{l}\text { Totally } \\
\text { applied }\end{array}$ \\
\hline \multirow[t]{2}{*}{$\begin{array}{l}\text { Project } \\
\text { initiation }\end{array}$} & Construction Request Management & & & & \\
\hline & $\begin{array}{l}\text { Annual Request Definition } \\
\text { Organizational rules for project } \\
\text { planning }\end{array}$ & & & & \\
\hline \multirow[t]{4}{*}{ Mobilization } & Develop all necessary bidding process & & & & \\
\hline & $\begin{array}{l}\text { Manage bidding processes in support of } \\
\text { the project }\end{array}$ & & & & \\
\hline & Manage contractual arrangements & & & & \\
\hline & $\begin{array}{l}\text { Manage all personnel for the project } \\
\text { development }\end{array}$ & & & & \\
\hline
\end{tabular}

\subsubsection{Model Management.}

Product design was developed alongside with BIM implementation. After project initiation, BIM implementation and execution plans were created. Although these 
documents had relevance, many of their items could not be applied, partially because of the relationship among the project stakeholders and different understandings between design office and project owners.

BIM execution plan was developed so that all other offices could adopt it to its designs, so local BIM implantation has since its initiation was created in order to become organizational BIM implantation guidelines.

Table 3 shows applicability evaluation of processes, where local guidelines were totally applied, and organizational guidelines are still being studied in order to apply it in other design offices.

Table 4. Evaluation of applicability and relevance of the process created.

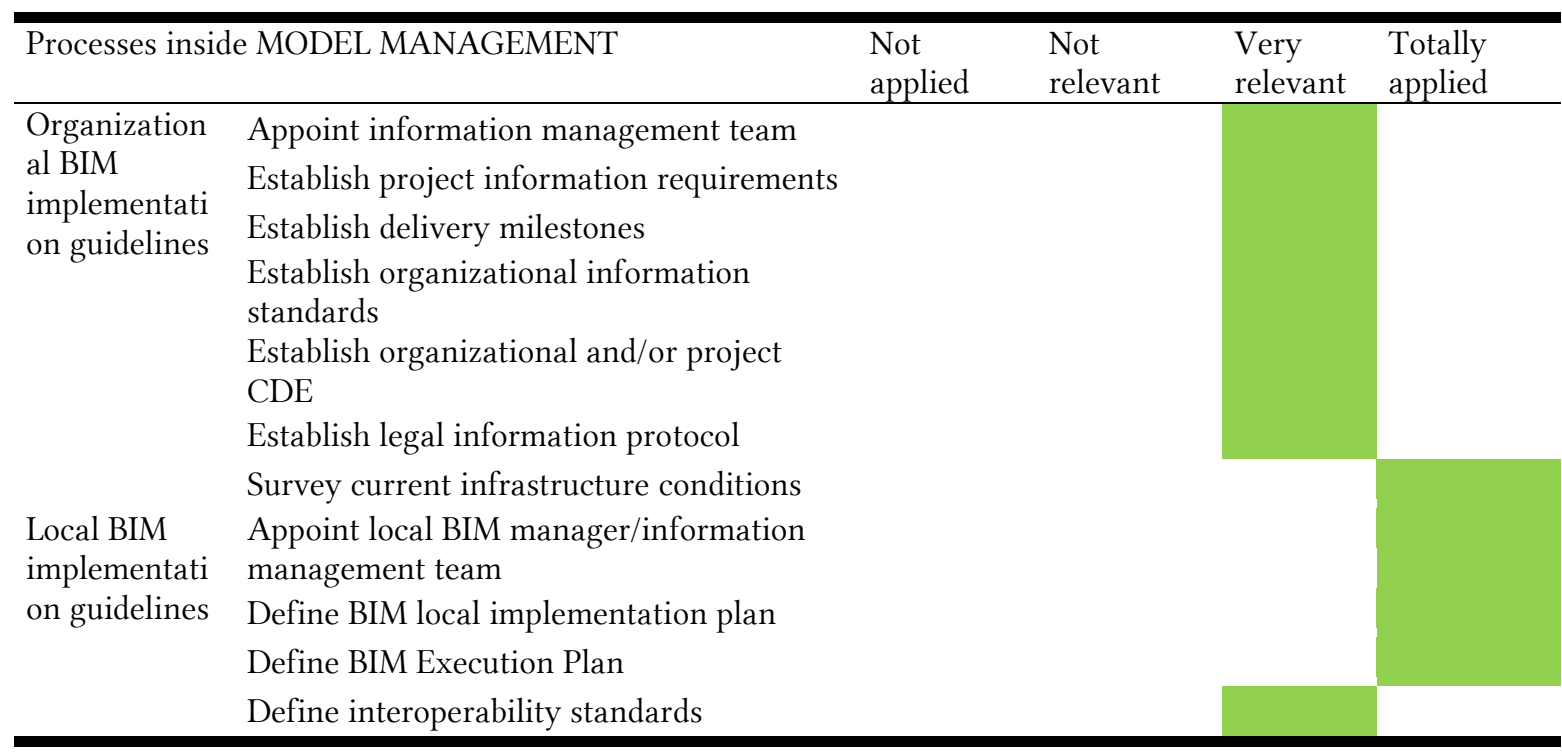

\subsubsection{Security Measures in BIModels}

There were several difficulties for any official adoption of security measures, as can be seen in Table 4. Most processes related to information security were applied only with respect to security breach information plans and personnel hiring policy, and they are already part of previous existing plans. In relation to BIModels, there were few contributions of security requirements to BIM implementation and execution plans. Design professionals received only basic security orientations and BIM consultants had little knowledge about the sensitive aspects of the project.

Table 5. Evaluation of applicability and relevance of the process created.

\begin{tabular}{|c|c|c|c|c|c|}
\hline \multicolumn{2}{|c|}{ Processes inside SECURITY ISSUES IN BIModels } & $\begin{array}{l}\text { Not } \\
\text { applied }\end{array}$ & Not relevant & $\begin{array}{l}\text { Very } \\
\text { relevant }\end{array}$ & $\begin{array}{l}\text { Totally } \\
\text { applied }\end{array}$ \\
\hline \multirow{5}{*}{$\begin{array}{l}\text { Organizational } \\
\text { directives }\end{array}$} & Appoint security information manager & & & & \\
\hline & Define security triage process & & & & \\
\hline & Define security strategy & & & & \\
\hline & Define security management plan & & & & \\
\hline & $\begin{array}{l}\text { Define security information } \\
\text { requirements }\end{array}$ & & & & \\
\hline \multirow[t]{2}{*}{$\begin{array}{l}\text { Local } \\
\text { directives }\end{array}$} & $\begin{array}{l}\text { Appoint security information } \\
\text { responsible }\end{array}$ & & & & \\
\hline & Define security management plan & & & & \\
\hline
\end{tabular}




\section{CONCLUSIONS}

The aim of this article was to develop processes which would contain all the main factors that guarantee an optimized development of a construction project with the use of BIM, also considering its sensitive aspects related to security-minded BIM.

The process were divided into three groups: model management, directly related to BIM implementation, with BIM execution plan and BIModel development; product management, directly related to design and to project at all their stages of development, and governance management, related by the demand for construction, project planning, and the development and execution of bidding documents and hiring processes.

From what is seen in this research, one can consider that the three groups constitute parts of a tri-axial conceptual structure where each one has a broad relationship with each other. In general, a BIM implementation usually occurs with the synergy of two projects: the BIM implementation itself in the organization that conducts and discipline the management of model information, and the development of a pilot project.

The guarantee of the success of any implantation in public environment is to manage both projects and make them compatible with public governance processes: hiring staff, purchasing means such as hardware, software, network solutions and specific training; mandatory legal analysis of all public management proceedings and finally, how all these activities are managed by the public organization. It was seen that most of these processes are not still known by the professionals not directly involved to the design: managers, owners, attorneys.

In view of the processes modeled and all their application to the office, most of them have been fully applied. Particularly product management processes benefited from the arrival of new technologies and collaborative information production processes.

BIM implementation processes, on the other hand, must necessarily consider the characteristics of the organization in which they are employed. In the specific case of this evaluation, the definition of organizational and internal guidelines was applied, albeit some tasks were not totally applied in organization.

In general, security issues in BIModels are very unfamiliar to design professionals, and its relationship with other processes groups is still unknown. All plans related to sensitive design must be developed prior to its initiation, and a specific security manager must be appointed by the organization.

\section{REFERENCES}

Associacao Brasileira de Normas Tecnicas. (2017). NBR 16636 Elaboracao e desenvolvimento de serviços técnicos especializados de projetos arquitetônicos e urbanísticos (In Portughese), Associacao Brasileira de Normas Tecnicas, São Paulo, Brazil.

British Standards Institute. (2015). PAS 1192-5:2015. Specification for security-minded building information modelling, digital built environments and smart asset management. British Standards Institute, London, United Kingdom.

Cheng, J. and Lu, Q. (2015). A review of the efforts and roles of the public sector for BIM adoption worldwide. Journal of Information Technology in Construction 20, pp. 442478. 
Dresch, A., Lacerda, D.P., and Antunes Junior, J.A.V. (2015). Design Science Research: a method for Science and technology advancement. 1st edn. Springer International Publishing, New York.

Eastman, C., Teicholtz, P., Sacks, R., Liston, K. (2008). BIM Handbook: A guide to building information modeling for owners, managers, designers, engineers, and contractors. 1st edn. John Willey \& Sons Inc., New Jersey.

Franca, A. J. (2016). Melhoria contínua aplicada a edificações de tipologia padronizada: a gestão do conhecimento no contexto do portfólio de ativos de uma organização. Ph.D. Diss., Architecture and Urbanism, University of São Paulo, São Paulo, Brazil.

$\mathrm{Gu}, \mathrm{N}$. and London.K. (2011): Understanding and facilitating BIM adoption in the AEC industry. Automation in Construction 31, pp. 204-214.

Holzer, D. (2016): The BIM managers handbook: guidance for professionals in Architecture, Engineering and Construction. 1st edn. John Willey \& Sons Inc., New Jersey.

International Standards Organization (2018). ISO 19650-1. Organization and digitization of information about buildings and civil engineering works, including building information modeling (BIM) - Information management using building information modeling - Part 1: Concepts and principles. International Standards Organization, Geneva, Switzerland.

(2018). ISO 19650-2. Organization and digitization of information about buildings and civil engineering works, including building information modeling (BIM) - Information management using building information modeling - Part 2: Delivery phase of the assets. International Standards Organization, Geneva, Switzerland.

(2019). ISO 19650-5. Organization and digitization of information about buildings and civil engineering works, including building information modeling (BIM) - Information management using building information modeling - Part 5: Security-minded approach to information management (draft in development). International Standards Organization, Geneva, Switzerland.

Manzione, E. (2013). Proposicao de uma Estrutura Conceitual de Gestao do Processo de Projeto Colaborativo com o uso do BIM (In Portughese), Ph.D. Diss., Civil Engineering, Universiy of São Paulo, São Paulo, Brazil.

Miceli Junior, G., Pellanda, P.C., and Reis, M.M. (2019). Implementation framework for BIM adoption and project management in public organizations, Proceedings of the 36th International Symposium on Automation and Robotics in Construction, Banff, Canada, pp. 114-121.

Pennsylvania State University (2011). BIM Project Execution Planning Guide - Version 2.1. Pennsylvania State University, Pennsylvania.

Pereira, A. (2017). Modelagem da informação da construção na fase de projeto: proposta de plano de execução BIM para a SUMAI/UFBA. (In Portughese), Ph.D. Diss., Architecture and Urbanism. Federal University in Bahia. Salvador, Brazil.

Porwal, A. and Hewage, K.H (2013). Building Information Modeling (BIM) partnering framework for public construction projects. Automation in Construction 31. pp. 204214.

Project Management Institute (2015). PMBOK Guide: a guide to the project management body of knowledge; 5 th edn. Project Management Institute.

Souza, F. (2016) A gestão do processo de projeto em empresas incorporadoras e construtoras. (In Portughese), Ph.D. Diss. Civil Engineering. University of São Paulo, São Paulo, Brazil. 
Succar, B. (2009). Building information modelling framework: A research and delivery foundation for industry stakeholders. Automation in Construction 18, pp. 257-275. 